\title{
Organizational Communication Dynamics in the Process of Integrated Information System in Muhammadiyah Healthcare Charity Venture
}

\author{
Wuri Rahmawati ${ }^{1, a)}$ Erwin Rasyid ${ }^{2)}$ \\ ${ }^{1}$ Universitas Aisyiyah Yogyakarta, Yogyakarta, Indonesia \\ a)author correspondence : wurirahma_w@unisayogya.ac.id \\ ${ }^{2}$ Universitas Aisyiyah Yogyakarta, Yogyakarta, Indonesia
}

_. DOI: https://doi.org/10.18196/jkm.121034

Article Info

Article history:

Received 1 Mar 2020

Revised 10 Apr 2020

Accepted 5 May 2020

\section{ABSTRACT}

As a progressing Islamic movement and one of the most prominent Islamic organizations, Muhammadiyah does not only focus on the religious field but also charity ventures in the fields of education, social, and health. Muhammadiyah's potential in developing its charity venture in the health sector is enormous. This study aims to analyze the dynamics of organizational communication in the process of coordinating the integration of the Muhammadiyah health information system. This qualitative research used a case study approach and in-depth interviews, observation, and archival documents, as the data collection technique. This research showed that the integration of health information systems in Muhammadiyah is challenging to realize due to the high potential of the sectoral ego in the process of managing the Muhammadiyah Healthcare Charity Venture (AUMKES). Supervising Council of General Wellbeing (MPKU) as an assembly responsible for planning, organizing, coordinating, and supervising the management of the health sector in Muhammadiyah needs to strengthen its capacity, especially in the area of organizational communication management. This is because MPKU PPM has not had enough power and legitimacy in uniting the perceptions of each RSMA manager.

Keywords: Health Information System; Muhammadiyah; Organizational Communication

\section{ABSTRAK}

Sebagai gerakan islam berkemajuan, Muhammadiyah tidak hanya fokus pada bidang keagamaan. Muhammadiyah juga dikenal sebagai organisasi islam terbesar di Indonesia yang menjalankan amal usahanya di bidang pendidikan, sosial dan kesehatan. Potensi Muhammadiyah dalam mengembangkan amal usahanya di bidang kesehatan sangat besar. Penelitian ini bertujuan untuk menganalisi bagaimana dinamika komunikasi organisasi dalam proses mengkoordinasikan integrasi sistem informasi kesehatan Muhammadiyah. Penelitian ini merupakan jenis penelitian kualitatif dengan menggunakan pendekatan studi kasus. Teknik pengumpulan data menggunakan teknik wawancara mendalam, pengamatan observasi dan dokumen arsip. Penelitian ini menunjukkan integrase system informasi kesehatan di Muhammadiyah sulit untuk diwujudkan. Hal ini dikarenakan oleh masih tingginya potensi ego sektoral dalam proses pengelolaan Amal Usaha Muhammadiyah bidang Kesehatan (AUMKES) di Muhammadiyah. Majelis Pembina Kesehatan Umum Pimpinan Pusat Muhammadiyah (MPKU PPM) sebagai majelis yang bertanggung jawab dalam perencanaan, pengorganisasian, pengkoordinasian dan pengawasan atas pengelolaan AUMKES perlu menguatkan kapasitas khususnya dalam bidang manajemen komunikasi organisasi. Karena MPKU PPM masih belum memiliki kuasa dan legitimasi yang cukup dalam menyatukan persepsi masing-masing pengelola Rumah Sakit Muhammadiyah Aisyiyah (RSMA).

Kata Kunci: Komunikasi organisasi; Muhammadiyah; Sistem informasi kesehatan 


\section{INTRODUCTION}

Transformation in the Islamic reformation movement in Indonesia just commenced in 1912 when Muhammad Darwis, or widely known as Kyai Haji Ahmad Dahlan, established Muhammadiyah. Muhammadiyah is a progressive Islamic movement deemed the representation of the modern urban middle class of Indonesia (Barton, 2014). In less than a century, Muhammdiyah has performed many philanthropy activities that contributed to the alteration of Indonesian social order (Jinan, 2016). Reformation movement of Muhammadiyah comprises three main aspects, religion, education, and society (Sutrisna, 2015). In the religious aspect, Muhammadiyah implemented its reformation movement through dakwah (missionary endeavor), focusing on the purification of Islamic doctrine. In the educational aspect, Muhammadiyah, until now, has established an educational system that ranges from primary to tertiary education in many areas of Indonesia. Also, in the social aspect, Muhammadiyah established various supporting facilities, such as hospitals, polyclinics, and orphanages.

In its reformation movement, Muhammadiyah burgeons various charity venture, which one of them focus in the healthcare field, namely AUMKES (Amal Usaha Muhammadiyah dalam Bidang Keseahatan/ Muhammadiyah Healthcare Charity Venture). In Indonesia, Muhammadiyah is widely recognized as one of the most prominent Islamic organizations that manage hundreds of clinics and hospitals and other educational institutions that concentrate on the healthcare field (Latief, 2010). A long history of Muhammadiyah movement in the healthcare field has been started from the colonial era with the establishment of General Misery Helper (PKO/Penolong Kesengsaraan Oemoem) as one of the Muhammadiyah charity ventures that worked on issues regarding social and healthcare. Initially, PKO was established in the form of a clinic and located in the Notoprajan and led by $\mathrm{dr}$. Somowidagdo. Today, the place mention lies at KH. Dahlan Street N0. 20, Yogyakarta.

PKO, which later changed its name into People Wellbeing Associate (PKU/ Pembina Kesejahteraan Umat), was officially established and became a part of the Muhammadiyah charity venture since the 1920s. PKU was a philanthropy movement of progressive Muhammadiyah. This movement flourished in the Muslim majority country and can live collectively with various communities despite ethnic, racial, and religious differences. The inclusive approach becomes the social capital of PKU and Muhammadiyah as an Islamic organization that concentrates on the social and healthcare field (Fauzia, 2017). The program of Muhammadiyah movement consolidation in the healthcare field ranges from healthcare, health development, health insurance, and training and education to improve the quality of the health workers (Purba \& Ponirin, 2013).

Muhammadiyah's potential in developing its charity venture in the healthcare field is enormous. Structurally, hospital, clinic, and Muhammadiyah's medical center, which are located in many different regions of Indonesia, are supervised by a council, called Supervising Council of General Wellbeing (MPKU/ Majelis Pembina Kesejahteraan Umum). The article of association and bylaw of Muhammadiyah instructs that a council is a supporting element of the boards, and its function is to run part of the main task of Muhammadiyah, namely executing charity ventures, programs, and main tasks in a particular field. The council is formed by the Central Board, Regional Board, Local Board, and Branch Board at each level as needed. This condition becomes a challenge for MPKU to develop organizational communication among AUMKES with its characteristics. Muhammadiyah is often perceived as an organization that is capable of running social entrepreneurship management and buttressing its each charity venture.

However, along with the development, Muhammadiyah's healthcare service is considered not maximal in developing breakthrough programs or innovation, although it can, for example, collaborate with tourism agencies to conduct health tourism and traveler medicine (Sutrisna, 2015). Besides, it is found that an integrated informational system among AUMKES is not available, making patient data are only owned by the RSMA, a place of patients received the diagnosis. Consequently, when a patient moved from one clinic to another (to another RSMA) owing to a particular reason, often, the patients follow the same process from the beginning and get re-diagnosed despite the same complaint. It affects the speed and accuracy of treating patient health. Therefore, to face challenges in industry 4.0, Muhammadiyah is expected to innovate its healthcare service. This objective can be realized through communication among stakeholders that are responsible for managing Healthcare Charity Venture (AUMKES) in Muhammadiyah by optimizing the advancement of technology. The process in message planning, selection in communication media channel, and approach and communication style are several elements that need to be considered (Rasyid et al., 2019). Since the 
essential function of organizational communication is message creation, interpretation, management in organization member activity (Ishak, 2012), and interaction among individuals in the organization, it creates micro and macrostructure that will determine the organization (Morissan, 2013).

This present research departs from the organizational communication perspective. Organizational communication in industry 4.0 is vital to be developed to make the process of communication in an organization effective. With the advancement of technology and the internet, a recommended development is by using an informational system in the AUMKES environment. This research aims to analyze the communication dynamics of organizations in the process of integration of the health information system in Muhammadiyah, specifically in terms of the management of Aisyiyah-Muhammadiyah Hospital (RSMA/ Rumah Sakit Muhammadiyah Aisyiyah (RSMA).

\section{METHODS}

This qualitative research used communication network analysis (CNA), or network analysis method to identify the communication structure in a system, in which relational data regarding communication flow was analyzed by using several types of interpersonal relationship as the analysis unit and focused on the relationship among individuals (Eriyanto, 2014). By mapping this relationship, the network analysis would help to reveal emergent and informal communication patterns that happen in an organization to be compared with the formal communication structure (Zwijze-Koning \& De Jong, 2005). In this research, snowball sampling was used to identify, select, and take samples continually in a network or connection chain from one respondent to another as a snowball. The network here was Muhammadiyah's stakeholders that figure in managing Muhammadiyah healthcare charity venture (AUMKES), namely Supervising Council of General Wellbeing (MPKU) and administrators of Aisyiyah-Muhammadiyah Hospital (RSMA). The data collection process was performed through in-depth interviews and observation, and supported by relevant documents or archives. These data were used to obtain information regarding communication process among Muhammadiyah stakeholder that manage AUMKES, especially RSMA. The data was analyzed by interactive analysis technique consisting of data collection, data reduction, data display, and conclusion.

\section{RESULT AND DISCUSSION}

Based on the Regulation of Central Board of Muhammadiyah Number 19/PRN/I.0/B/2015, Supervising Council of General Wellbeing (MPKU) is a supporting element of Union Board (Pimpinan Persyarikatan) that is ordered to conduct charity ventures, programs, and central activity in the healthcare field, as adjusted to the policy of Union Board in each level. The structure of MPKU consist of the head and vice head; secretary and vice secretary; treasurer and vice treasurer; and head and the member of a sector needed.

One of the functions of MPKU is to plan, organize, coordinate, and supervise the management of charity ventures, programs, and activities. MPKU also has responsibility and power towards establishments and dismissals of the charity venture set by the Union Board at each level. The regulation of 19/PRN/I.0/B/2015 also regulates the duty of MPKU that can propose an appointment and discontinuation of Daily Associate Agency (BPH/Badan Pembina Harian) of Healthcare Charity Venture (AUMKES). Although it is the Union that signed the Decree (SK) of appointment at each level that manages the hospital. It was explained by Agus Syamsyuddin, the 2015-2020 head of MPKU:

If a branch has a hospital, the decree is from the regional board. If a local board has a hospital, the decree is from the regional board. If a regional board has a hospital, the decree is from the central board. (Syamsyudding, A., Personal interview, 2020).

Concerning how the structure of the communication in the coordination process of the health information system in Muhammadiyah integrates, the researcher investigation showed that the process or stages of related stakeholders were not sufficient. By far, AUMKES in Muhammadiyah still performed a system and standard that was set independently by each administrator. That is, Muhammadiyah had no integrated health information system. It was shown by dr Ahmad Faesol, the chairman of the hospital of PKU Muhammadiyah Gamping, who is also a member of the Hospital Development Sector and Rudimentary Service in (Bid.PRS\&PD) MPKU. 
MPKU has not integrated one hospital with another hospital. However, in the future, we are planning on at least establish the Single ID. However, we have not met the IT expert. (Faesol, A, personal Interview, 2020)

The statement from dr. Ahmad Faesol is consistent with Subur Yuswanto, a member of Bid.PRS\&PD that was responsible for arranging the standard of the informational system of Aisyiyah Muhammadiyah Hospital (RSMA).

For now, Muhammadiyah's network has not been integrated. For example, someone in Jakarta cannot access the medical record in Yogyakarta. This is because the center is in each hospital. We do not have big data, although it would be better if we have one. However, this is risky, considering competitors outside Muhammadiyah's environment. What is online is the financial report to Muhammadiyah central board, as well as the legal entity (1), pharmaceutical budget (1), and banking access (1), but because we are afraid of being hacked or stolen by other parties, the patient medical record has not gone online. However, people can register and access the hospital online. (Yuswanto, S., Personal interview, 2020)

One of the work programs of MPKU in the period 2015-2020 is to develop a Health Information System of RSMS (SIK RSMA). However, four factors halted the realization of the integrated health system of Aisyiyah Muhammadiyah. The first is the management of AUMKES, primarily RSMA, that had different standards and resources.

For the same system, I might agree. Until now, the old system is complicated to apply, not to mention that the number and variety of our hospital is humongous. Ranging from a hospital that only has around twenty beds to PKU solo that has more than 300 beds, if I am not mistaken. In other words, the gap is enormously significant. When we are planning on making an information system of hospital management, it means it should be applied to all hospitals. Big hospitals that have struggled to create a system, when a new system appears, they might reject it. The level of rejection would be high because they should alter their habit; would they not? How to fill and how to do so-and-so would be different. At first, we thought the idea of the same system, but we think why do not we function as the Ministry of Health. The Ministry of Health also has numerous hospitals, and the system in each hospital is different. (Rini, E, Personal Interview, 2020)

The second problem is that it was difficult for MPKU to collect all information regarding the development of RSMA in each region. The administrators of RSMA was not obliged to report the development of RSMA to MKPU. The report was merely for the Ministry of Health and its BPH. It is consistent with what dr. Eko Rini Listiowati observed:

So, the current hospital has five reports that are continually sent to the Ministry of Health, but we have never received one. The hospitals grow bottom-up. They do not feel they have an obligation to present the report to MPKU. They only make reports to their BPH or their regional MPKU. The reports have never reached the union that organizes and MPKU. Consequently, MPKU data are not updated. Even the number of beds is not updated. That what happens. The second is I think these five reports have been comprehensive enough, but I do not remember. The names are RL 1 to RL 5, but I do not know who will get the RL 1. However, the contents include the profile of the hospital, as well as the demographics. We know who the patients are. (Rini, E., Personal Interview, 2020)

By far, the boards dominated the initiation of the establishment of RSMA were at the level branch or local. Around 30-40\% of RSMA until now was initiated by the Branch Board of Muhammadiyah (PCM/ Pengurus Cabang Muhammadiyah). The rest were established and managed by the Local Board. Consequently, the potency of the egocentrism among the administrator of RSMA was high.

One of the weaknesses of Muhammadiyah is the appointment of directors or management of the hospitals that is not centralized. Why is it not centralized? The union establishes the hospital of Muhammadiyah. The Muhammadiyah hospital can be established by PCM, PRM, PDM, and PP. Some hospitals even are established at the level of the village, e.g., PKU Muhammadiyah Hospital Sekapuk Surabaya that was established by PRM. Then, almost the majority, around $30-40 \%$, is established by the branches, the rest are PDM. For coordination, first, there would be egocentrism in each hospital. Second, there will be a disagreement because there would be checking while the hospitals are established by the branch or local boards. (Yuswanto, S, Personal Interview, 2020) 
Based on the respondent statement, it can be seen that each RSMA had its authority in managing the institution, ranging from the human resource to financial and healthcare issues. This is because the institutional structure established the RSMA, whether at the level of twig, branch, or local. Often the coordinative function of supervision that cling to the founder issued egocentrism among RSMA. As a result, any attempt to unite or make the standard of institutional management identical nationally was complicated. Furthermore, hospitals that were dominated by the PCM and PDM impeded consolidation among regions and centers. Consequently, the role of MPKU was only limited to coordination that gave direction and recommendation to each RSMA's management.

By far, there is no regional board that has a hospital, either local or local boards that have one. That is the difference. This is the reason our colleagues in the branch boards are more comfortable with consolidating since they hold the decree, do not they? In Dikti, structurally, every university follows the rules, while we tend to be coordinative. (Syamsuddin, A, Personal Interview, 2020)

Thirdly, the expensive cost of SIK development and domination of BPJS in funding most of the patients were the factors why the RSMA administrator had not made SIK as the priority program.

Probably, one of the problems is the resources. Scholars in the university are more literate towards IT than hospital workers. Nowadays, the cost of complaints of the hospital is tighter after BPJS. Therefore, investment in IT is considered many times, except they have one person that is smart enough to fabricate the system by himself. If we have to buy it, it feels expensive. (Syamsuddin, A., Personal Interview, 2020)

It can be inferred from the passage that the partnership between MPKU, RSMA, and the Universities of Muhammadiyah Aisyiyah (PTMA) is vital to assist in realizing SIK RSMA PTMA to have human resources in terms of IT that can develop SIK RSMA so that it can diminish the budget of procurement that needs to be done by the RSMA. With this partnership, it is expected that the university can motivate the administrator of RSMA to make SIK a priority program.

In addition, to anticipate the expensive cost of SIK RSMA, MPKU, as the council that supervises the AUMKES, should still attempt in searching for the prototype of SIK that can be implemented by the administrator of RSMA. It can be done through a comparative study and partnership with vendors that apply digital platforms in the healthcare field.

I am planning on going to Tulungagung because that city gets awards in an Asia competition for its use of hospital informational systems. It was a Regional Public Hospital. We are planning on going there. I might not know, but the plan is they will give us some information if I am not mistaken. The advantage of the information in the Tulungagung Regional Public Hospital for me is this; if we partner with a vendor, it will be costly. If we want self-development, we have to conduct another partnership. In Gamping, I make a partnership with MyHospital, MyAccounting, ad MyHRD. (Rini, E., Personal Information, 2020)

Some administrator of RSMA that was a part of MPKU's board was planning on developing a system called Single ID. The Single ID is informational storage regarding patient data that are needed by every healthcare unit.

For integration, admittedly, we have not gone that far since most of them are growing independently. What we do is gradually making standardization of the proper services. After that, we can imitate each other, in a quotation, imitate what is excellent. So, the IT system can collectively develop. Secondly, the use of the Single ID. It will be the embryo. However, beforehand, it runs sporadically. So, anything that we see promising, we do that (Syamsuddin, A., Personal Interview, 2020).

Although the development of the prototype of the Single ID was still limited in several regions, this innovation would be a promising initial step for the MPKU in developing SIK that can integrate RSMA throughout Indonesia.

Yesterday, we were from MPKU Jogja encourage PKU Jogja, "let's make the Single ID system." However, the representative from Bantul asked me back, "what are the advantages of the single ID? There are a lot. For example, Bantul people can have a check-up in Jogja or Gamping by using the same ID, namely e-KTP, by using the NIK. Although Bantul has not been encouraged to start that, I may start from Jogja and Gamping. The plain is that at least we realize it in 
Muhammadiyah's environment, such as in PKU Jogja, Gamping, Bantul, Kota Gede, Wonosari, and Sleman. However, it must be hard if we directly start it since each hospital has a different informational system. In the past, MPKU used to plan to integrate hospital informational systems throughout Indonesia, starting from the Health Cloud. Until now, the element that runs is the reportage process. It also has not optimum. Although the Health Cloud has been active, the program has not worked thoroughly. It can be used as facilities and medium to report the hospital data that is integrated with the central. Health Cloud has existed if the hospitals use it as a part of the report gained. (Faesol, A., Personal Interview, 2020)

Though the development of Single ID, MPKU is the potential to develop integrated SIK RSMA. Today the Single ID is still in development in some hospitals, which have adequate capabilities and resources.

Centrally, the Single ID has not been applied; however, for each hospital, this system has been activated. For example, here, the Single ID has been proper enough. We have entered the emedical record stage. This is conducted electronically. When a doctor or physical want to know the result, comment, or visit, they can access it through its cell phones. It is similar to the Halo Doctor application, but the system is our own. So, if each hospital, I think, has developed the system independently. Moreover, if we want to make it prettier, it should be polished together with MPKU. (Faesol, A., Personal Interview, 2020)

The main challenge of the development of the Single ID today is the method or technique to integrate the system into the civil registration, which was owned by the related institution, especially with the E-KTP as the primary civil registration in Indonesia.

We are trying the Single ID, but we have to make a partnership with the Department of Civil Registration (Dukcapil) since the only identity that is identical is E-KTP. It is what we will use. We have partnered with the Department of Civil Registration in Sleman, but it is only in Sleman. We still have one in Jogja, Not to mention that if we are partnering with RSIJ, since Jogja, Jakarta, Surabaya are big cities that may have the traffic of the busy Muhammadiyah movement. So, that is the problem. It is not easy, but we then try the input method. So, the ID cards are inputted. However, if we have partnered with the Department of Civil Registration, when we scan that, all the individual data will show up. So, we only need some related data, such as where was the last time he got checked? How is medical history? Does he have an allergy, does he have a chronic illness? All critical questions about the information that might disappear. Dm and hypertension will not disappear. Data regarding allergy, such as penicillin, should be included. It is not easy to complete. PKU in the city, Gamping, and RSIK Cempaka Putih Jakarta are trying. First, We look at these three hospitals as the models. It can be said that we try the portable system first. If the prototype succeeds, we then develop it. However, by far, it seems that we need to partner with the Department of Civil Registration for the use of E-KTP that can maximize the scanning of the KTP (Rini, E. Personal Interview, 2020).

The dynamic that happened in the development of SIK RSMA showed that strengthening the communication among institutions, whether among MPKU itself, between MPKU and RSMA, or among RSMA, is vital. MPKU should be capable of being the opinion leader and gatekeepers in managing communication networks among stakeholders in Muhammadiyah.

What is the target? Principally, we only want to map the stakeholder. However, the most critical point is to ask whether the system does exist. Then we can see the hospital inter-organizational communication, whether among hospitals or with MPKU as the council and the networks. In Jogja, since the systems have not been built, we visit the hospital/ supervision, and then the sister hospital. After observing the condition of the hospital, after supervision, if there is something that we can support, we support it. (Faesol, A., Personal Interview, 2020.

Organizational communication theory that was used for analyzing the dynamics of the Muhammadiyah stakeholder communication in this research was the CommonKADS communication model. This approach consists of some inputs, namely task, knowledge, agent, communication plan, information exchange specification, and task structure. This CommonKADS communication model aims to determine the procedure of specification of information and realize the process of knowledge 
transfer among agents in an organization. The interaction process explained in this CommonKads communication model can be seen in the figure below.

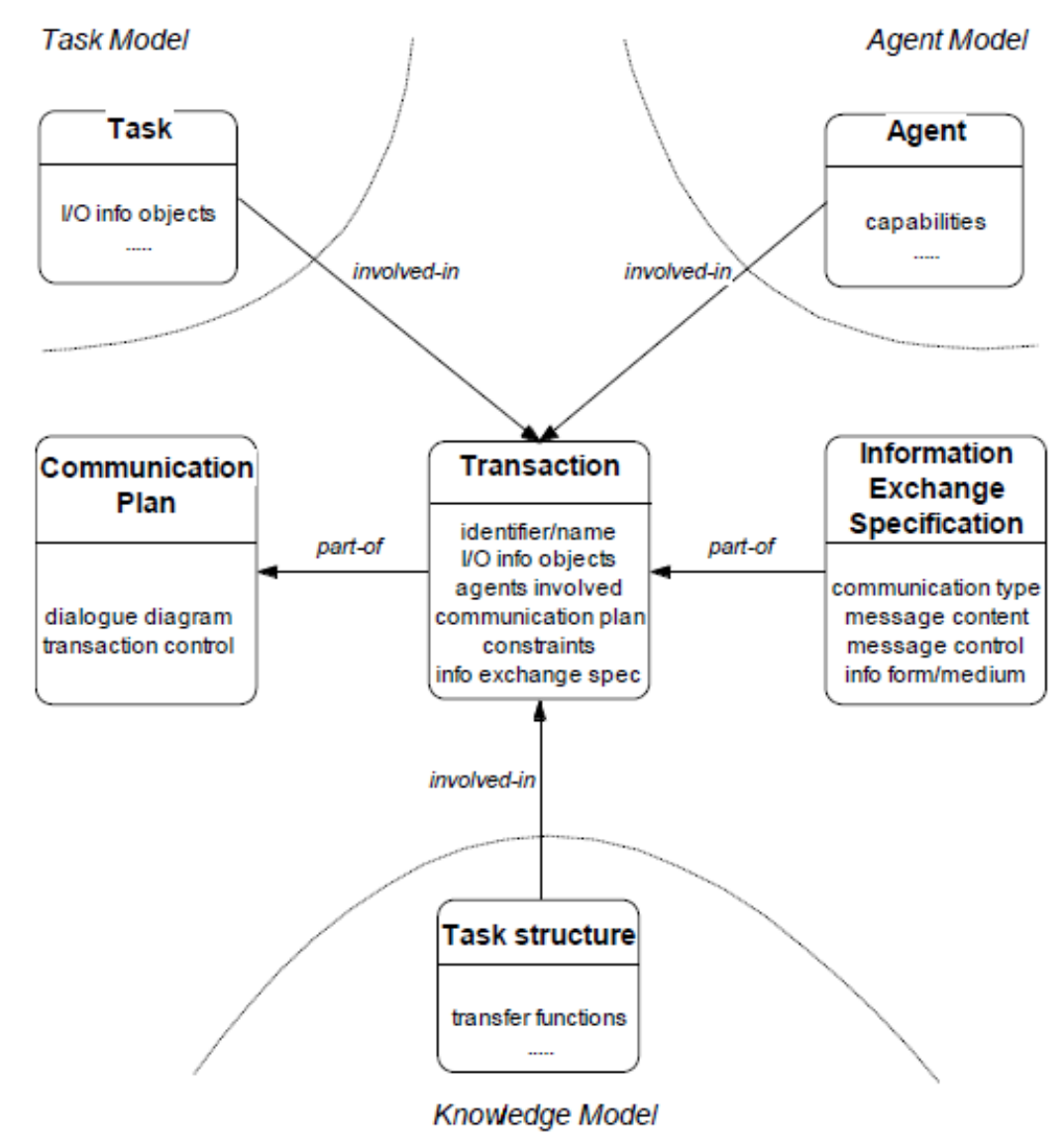

Figure 1. CommonKADS Communication Model(Schreiber et al, 2000)

The critical components of the CommonKADS communication model describe communicative action that is done by each actor within it. In the component, there is a transaction process that can provide exchanged information by the Muhammadiyah stakeholders, which in this case, was MPKU and the administrator of RSMA. This transaction comprises of type and communication that has been determined, making it easier to create structure message protocol (Schreiber, 2000).

There are three layers in the transaction process of the CommonKADS communication model. The first is the communication plan that manages dialog among actors. The second is transaction among actors that relate two different tasks from the actor that is involved within it. The last is the specification regarding the exchanged message that specifies the structural message in the inner side of the organization.

The essential part of the organizational communication process is to display the meaning of a message so that it can be considered identical by the massage giver and receiver (Kuswarno, 2001). Besides the message interpretation process, the component that determines the behavior and relationship among communicators with communicant in an organization is the number of message and behavior involved in the process of such organizational communication. The dynamics of communication in the integration process of SIK RSMA in Muhhmadiyah showed that the differences in character between communicator and communicant that was played by the MPKU or RSMA organizer were varied. It caused the emergence of various messages or interests among stakeholders that were difficult to unite or compromise. Consequently, until now, integrated SIK RSMA has not been realized.

The biggest obstacle for the smoothness of communication flow is a state or attitude that has embedded or been a culture in the organization. For example, a physical distance among people and 
far apart location impact the flow since the time needed in the communication system of the organization calls for quite a long time, as well as winding and complicated process (Rahmanto, 2004). This thing was also a big challenge in the process of realizing integrated SIK RSMA. The spread of RSMA in various different places in Indonesia became the obstacle of MPKU in communicating with each administrator of MPKU.

The organization is demanded to deal with a more complex world. If, in the classic communication approach, organizational communication is limited by the direction of the communication, the medium, and communication style, now, the strategy and concept of organization and communication should be reconsidered. This is because the concept and strategy would be used as an approach to understanding organizational communication (Miller, 2006). It is also a challenge for MPKU as the council that figures in being the central point in the communication network for the development and management of AUMKES, primarily Muhammadiyah's RSMA Muhammadiyah. MPKU is required to design a communication model and strategy that can unite each interest of RSMA administrator so that all parties will accept the decision.

The Decision-making process in an organization is a complex process that involves many stages. Messages and members of the organization will be seen as a part of the knowledge management system. The organization is not faced with the duty to interpret a message but also a challenge to determine the party that should receive the information for achieving organizational targets (Ramadani et al., 2015). The collective decision realizing integrated SIK RSMA depends highly on the development method or strategy of MPKU's capability as the council that is ordered to coordinate all Muhammadiyah's AUMKES. It is vital since interactive and interdependent communication consists of communication, message, media, communication, and effect of communication in achieving organizational goals through the division of labor and hierarchal function of authority and responsibility (Farihanto, 2017).

\section{CONCLUSION}

The research has shown that each Muhammadiyah Aisyiyah Hospitals (RSMA) has its authority to manage its institution regarding human and financial resources, healthcare service, and so forth. The process of consolidation, coordination, and supervision of RSMA was similar to the establishment process that was generally done by the Muhammadiyah Local Board (PDM) and Muhammadiyah Branch Board. The development of the Health Information System (SIK RSMA) faced various problems; namely, each AUMKES had different resources. MPKU struggled in collecting information regarding the development of RSMA in each region. The reason is that the report of RSMA was only delivered to the Ministry of Health and its BPH. Furthermore, the development of SIK called for expansive cost so that it had not been a priority program. MPKU, together with some RSMA, had started to initiate the Single ID and had entered the stage of e-medical records, namely saving the data of the patients electronically. The main challenge in developing the Single ID was the method or technique to integrate the system into registration civil in Indonesia. Many dynamics in the development of integrated SIK RSMA called for a strengthening of inter-institution organizational communication, whether between MPKU and RSMA or among RSMA. MPKU should be the opinion leader and gatekeepers in managing communication networks among health stakeholders in Muhammadiyah so that the responsibility in planning, organizing, coordinating, and supervising of the AUMKES's management can run optimally.

\section{ACKNOWLEDGMENT}

The present research is sponsored by the Council of Tertiary Education in Research and Development (Diktilitbang) of Muhammadiyah Central Board through 2019 Muhammadiyah Research Grant. 


\section{REFERENCES}

Barton, G. (2014). The Gülen Movement, Muhammadiyah and Nahdlatul Ulama: Progressive Islamic Thought, Religious Philanthropy and Civil Society in Turkey and Indonesia. Islam and Christian-Muslim Relations, 25(3), 287-301. https://doi.org/10.1080/09596410.2014.916124

Farihanto, M. N. (2017). Komunikasi Organisasi dalam Penanaman Budaya Organisasi di Seminari Tinggi Santo Paulus Yogyakarta. Jurnal ILMU KOMUNIKASI, 10(2), 179-194. https://doi.org/10.24002/jik.v10i2.352

Fauzia, A. (2017). Penolong kesengsaraan umum: The charitable activism of muhammadiyah during the colonial period. South East Asia Research, 25(4), 379-394. https://doi.org/10.1177/0967828X17740458

Ishak, A. (2012). Peran Public Relations Dalam Komunikasi Organisasi. Jurnal ASPIKOM, 1(4), $373-380$.

Jinan, M. (2016). Muhammadiyah Studies: The Transformation of Research on Islamic Movement in Indonesia. Analisa, 22(2), 269. https://doi.org/10.18784/analisa.v22i2.96

Kuswarno, E. (2001). Efektivitas Komunikasi Organisasi. Mediator, 2(1), 55-61. https://doi.org/10.1007/s13398-014-0173-7.2

Latief, H. (2010). Health provision for the poor: Islamic aid and the rise of charitable clinics in Indonesia. South East Asia Research, 18(3), 503-553. https://doi.org/10.5367/sear.2010.0004

Miller, K. (2006). Organizational Communication: Approaches and Processes. Boston: Wadsworth Cengage Learning.

Morissan. (2013). Teori Komunikasi: Individu hingga Massa. Jakarta: Kencana.

Purba, I. A., \& Ponirin. (2013). Perkembangan Amal Usaha Organisasi Muhammadiyah di Bidang Pendidikan dan Kesehatan. Jurnal Ilmu Pemerintahan Dan Sosial Politik UMA, 1(2), 101111.

Rahmanto, A. F. (2004). Peranan Komunikasi Dalam Organisasi. Jurnal Komunikologi, 1(2), 59-75. https://doi.org/10.1016/j.ntt.2003.10.009

Ramadani, D., Lestari, P., \& Susilo, M. E. (2015). Audit Komunikasi Organisasi Wahana Lingkungan Hidup Indonesia (Walhi) Yogyakarta. Jurnal ASPIKOM, 2(4), 282-290.

Rasyid, E., Partini, P., Haryadi, F., \& Zulfikar, A. (2019). Jaringan komunikasi dalam pengelolaan perencanaan program penanggulangan kemiskinan di Provinsi Sulawesi Barat. Jurnal Kajian Komunikasi, 7(2), 133-144. doi:http://dx.doi.org/10.24198/jkk.v7i2.19574

Schreiber, G., Akkermans, H., Anjewierden, A., Hoog, R. de, Shabolt, N., Velde, W. Van de, \& Wielinga, B. (2000). Knowledge Enginering and Management. London: The MIT Press.

Sutrisna, E. (2015). Muhammadiyah dan Gerakan Kesehatan Berkemajuan. Tajdida, 13(1), 9-16. 